\section{The role of uncoupling protein 2 (UCP2) on the development of type 2 diabetes mellitus and its chronic complications}

\author{
Papel da proteína desacopladora 2 (UCP2) no desenvolvimento \\ do diabetes melito tipo 2 e de suas complicações crônicas
}

Bianca Marmontel de Souza',3, Taís Silveira Assmann', Lúcia Maria Kliemann², Jorge Luiz Gross ${ }^{1,3}$, Luís Henrique Canani ${ }^{1,3}$, Daisy Crispim ${ }^{1,3}$

\section{SUMMARY}

It is well established that genetic factors play an important role in the development of type 2 diabetes mellitus (DM2) and its chronic complications, and that genetically susceptible subjects can develop the disease after being exposed to environmental risk factors. Therefore, great efforts have been made to identify genes associated with DM2. Uncoupling protein 2 (UCP2) is expressed in several tissues, and acts in the protection against oxidative stress; in the negative regulation of insulin secretion by beta cells, and in fatty acid metabolism. All these mechanisms are associated with DM2 pathogenesis and its chronic complications. Therefore, UCP2 is a candidate gene for the development of these disorders. Indeed, several studies have reported that three common polymorphisms in UCP2 gene are possibly associated with DM2 and/or obesity. Only a few studies investigated these polymorphisms in relation to chronic complications of diabetes, with inconclusive results. Arq Bras Endocrinol Metab. 2011;55(4):239-48

\section{Keywords}

UCP2; type 2 diabetes mellitus; diabetic retinopathy; diabetic nephropathy; DNA polymorphisms; haplotype

\section{SUMÁRIO}

Está bem estabelecido que fatores genéticos têm papel importante no desenvolvimento do diabetes melito tipo 2 (DM2) bem como de suas complicações crônicas e que indivíduos geneticamente suscetíveis podem desenvolver essa doença após exposição a fatores de risco ambientais. Assim, grandes esforços têm sido feitos para a identificação de genes associados ao DM2. A proteína desacopladora 2 (UCP2) é expressa em diversos tecidos e atua na proteção contra o estresse oxidativo, na regulação negativa da secreção de insulina pelas células-beta e no metabolismo dos ácidos graxos, mecanismos associados tanto à patogênese do DM2 como a suas complicações crônicas. Portanto, o gene UCP2 é um gene candidato para o desenvolvimento dessas doenças. De fato, diversos estudos têm relatado que três polimorfismos comuns no gene UCP2 estão possivelmente associados ao DM2 e/ou à obesidade. Apenas poucos estudos investigaram esses polimorfismos em relação às complicações crônicas do diabetes, obtendo resultados pouco conclusivos. Arq Bras Endocrinol Metab. 2011;55(4):239-48

\section{Descritores}

UCP2; diabetes mellitus tipo 2; retinopatia diabética; nefropatia diabética; polimorfismos de DNA; haplótipo

\author{
1 Endocrinology Division, \\ Porto Alegre, RS, Brazil \\ 2 Pathology Service, Hospital \\ de Clínicas de Porto Alegre, \\ Porto Alegre, RS, Brazil \\ ${ }^{3}$ Graduate Studies Program in \\ Medical Sciences, Endocrinology, \\ Universidade Federal do \\ Rio Grande do Sul (UFRGS), \\ Porto Alegre, RS, Brazil
}

\author{
Correspondence to: \\ Daisy Crispim \\ Rua Ramiro Barcelos, 2350 \\ prédio $12,4^{\circ}$ andar \\ 90035-003 - Porto Alegre, RS, \\ Brazil \\ daisy_crispim@hotmail.com
}

Received on Feb/22/2011 Accepted on Apr/29/2011

\section{INTRODUCTION}

$\mathrm{I}$ $t$ is estimated that $7.6 \%$ of the Brazilian population have diabetes mellitus (DM) (1). This disease constitutes a serious public health problem because of its high prevalence, increased morbidity and mortality rates, and economic and social repercussions arising from the impact of its chronic complications, which compromise both the quality of life and productivity of affected subjects, besides the high costs of treatment (2). 
Type 2 DM (DM2) accounts for 90\%-95\% of DM cases worldwide and usually occurs in obese subjects over 40 years of age. It is characterized by hyperglycemia due to a combination of insulin resistance (IR) and inadequate compensatory insulin secretion (2). Chronic hyperglycemia is associated with long-term structural damage, dysfunction, and failure in several organs and tissues, which consequently lead to the development of chronic complications (2). These complications are often categorized as microvascular (retinopathy, nephropathy and neuropathy), or macrovascular (cardiovascular and cerebrovascular) (2). Among chronic microvascular complications of diabetes, diabetic retinopathy (DR) is the leading cause of blindness in adults (3); diabetic nephropathy (DN) is the most common cause of end-stage chronic renal disease and kidney transplants in many countries (4); and diabetic peripheral neuropathy (DPN) is responsible for $50 \%$ $75 \%$ of non-traumatic lower limb amputations (5). Genetic factors play an important role in the development of DM2 and its chronic complications, and genetically susceptible subjects can develop this disease after being exposed to environmental risk factors. Therefore, great efforts have been made to identify genes associated with DM2 and its chronic complications (2).

Uncoupling protein 2 (UCP2) plays important roles in decreasing the production of reactive oxygen species (ROS) by mitochondria, regulating insulin secretion by pancreatic beta cells, and regulating free fatty acid (FFA) metabolism, which are mechanisms directly associated with the pathogenesis of DM or its chronic complications (6). Thus, the aim of this study was to review the role of UCP2 in relation to the development of DM2 or its chronic microvascular complications.

\section{THE MITOCHONDRIAL RESPIRATORY CHAIN (MRC)}

Mitochondria are essential organelles in all eukaryotic cells, and regulate a number of key vital processes for cell survival and function, including energy production, redox control, calcium homeostasis, and certain metabolic and biosynthetic pathways. In addition, mitochondria are the main sources of ROS, and often play an essential role in physiological cell death mechanisms (7).

The main source of cell energy is the synthesis of adenosine triphosphate (ATP) from adenosine diphosphate $(\mathrm{ADP})$ and inorganic phosphate $(\mathrm{Pi})$, by means of oxidative phosphorylation carried out in the mito- chondrial respiratory chain (MRC) (8). MRC is located in the mitochondrial inner membrane, and has five multienzymatic complexes and two proteins responsible for electron transport, cytochrome $c$ and coenzyme Q (Figure 1A). Oxidative phosphorylation involves coupling electron transport to the active pumping of protons across the mitochondrial inner membrane and generation of ATP in the MRC (7).

Oxidation of reduced nutrient molecules, such as carbohydrates, lipids, and proteins in cell metabolism generates electrons in the form of reduced hydrogen carriers (NADH and FADH2), which are referred as reduced cofactors. These reduced cofactors donate electrons to the MRC. The movement of electrons through the components of the MRC is driven by a redox potential along the chain. Complexes I, III and IV pump protons across the inner membrane, as electrons pass down the chain complexes. This produces an electrochemical potential difference across the inner membrane, known as proton-motive force, $\Delta p$, consisting mostly of an electrochemical gradient (membrane potential) and a small chemical gradient (difference in $\mathrm{pH}$ ). The energy that is conserved in the proton gradient across the inner membrane is used by complex $\mathrm{V}$ $\left(\mathrm{F}_{1} \mathrm{~F}_{0}\right.$-ATP synthase) to synthesize ATP, as protons are transported back from the intermembrane space into the mitochondrial matrix. The final destination for the electrons is the generation of molecular oxygen, which is reduced to water by complex IV, in the last step of the MRC. Therefore, the process of substrate oxidation and oxygen reduction is also called respiration $(7,8)$.

ROS correspond to a variety of molecules and free radicals (chemical species with one unpaired electron) derived from the metabolism of molecular oxygen. Superoxide anion $\left(\mathrm{O}_{2}^{-*}\right)$, the product of an one-electron reduction of oxygen, is the precursor of most ROS, and a mediator in oxidative chain reactions (7). Dismutation of $\mathrm{O}_{2}^{-*}$ (either spontaneously or by means of a reaction catalyzed by superoxide dismutases) produces hydrogen peroxide $\left(\mathrm{H}_{2} \mathrm{O}_{2}\right)$ which, in turn, may be fully reduced to water or, in the presence of ferrous or cuprous ions, may form the highly reactive hydroxyl radical $(\cdot \mathrm{OH})(7)$.

ROS normally exist in all aerobic cells in balance with biochemical antioxidants. Oxidative stress occurs when this critical balance is disrupted because of excess ROS, antioxidant depletion, or both. This stress causes damage to cellular macromolecules such as nucleic acids, proteins, structural carbohydrates, and lipids. 


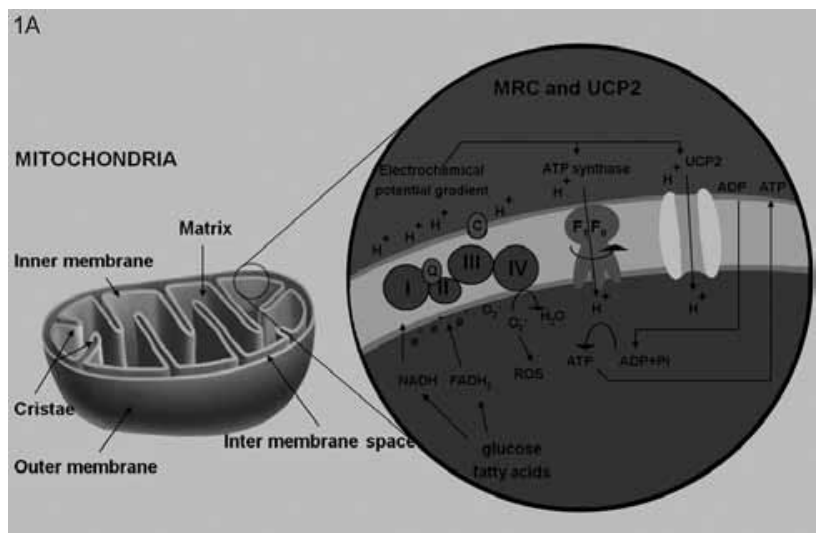

$1 \mathrm{~B}$

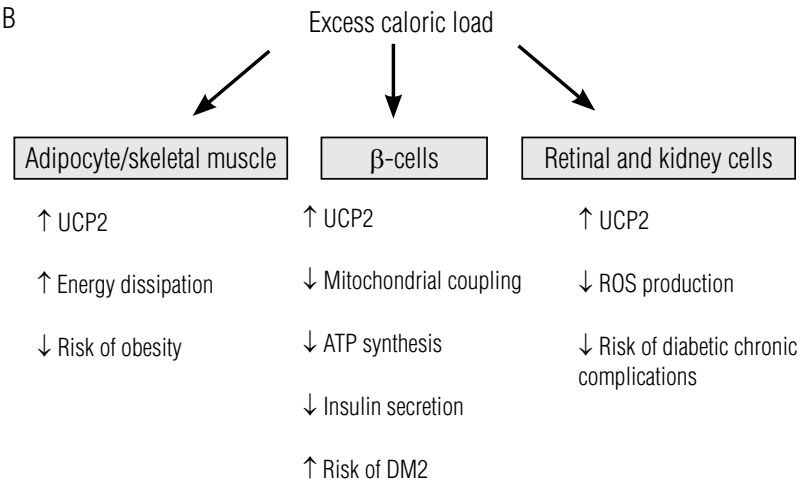

Figure 1. Energy dissipation mediated by UCP2 and its roles in obesity and type 2 diabetes mellitus (DM2). 1A) UCP2 location and function in the mitochondrial respiratory chain (MRC). Numbers I-IV correspond to MRC complexes. $F_{1} F_{0}$-ATP synthase is the fifth complex of MRC. During respiration, protons are pumped by MRC complexes and a proton electrochemical potential gradient is generated. The energy of the proton gradient drives the synthesis of ATP by the $F_{0} F_{1}$ complex. UCP2 catalyzes a regulated re-entry of protons into the matrix, uncoupling MRC and, consequently, reducing ATP synthesis. 1B) Main roles of UCP2 in obesity and DM2. ROS = reactive oxygen species. $Q=$ coenzyme $Q ; C=$ cytochrome-c.

It is well-established that there is a strong positive correlation between mitochondrial inner membrane potential and production of ROS. At high membrane potentials, even a small increase in this potential greatly stimulates $\mathrm{H}_{2} \mathrm{O}_{2}$ production. Therefore, "mild uncoupling", i.e., a small decrease in membrane potential, has been suggested to have a natural antioxidant effect (9).

\section{MITOCHONDRIAL DYSFUNCTION AND TYPE 2 DIABETES MELLITUS}

In the past decade, several clinical and experimental studies have strengthened the hypothesis that mitochondrial dysfunction, including reduction in the num- ber of mitochondria and in the efficiency of oxidative phosphorylation, is closely associated with DM2 (10). Microarray analyses performed in biopsies of skeletal muscle of DM2 patients and non-diabetic subjects from different populations have shown that PGC- $1 \alpha$ (PPAR- $\gamma$ coactivator- 1$)$, the master control in the regulation of mitochondrial biogenesis, and NRF-1 (nuclear respiratory factor-1), as well as their downstream target genes in oxidative metabolism, are decreased in DM2 patients $(10,11)$. These findings were confirmed by enzymatic studies that reported that DM2 patients, or their insulin-resistant offspring, show a decline in mitochondrial oxidative activity (12), in insulin-stimulated ATP synthesis and fatty acid oxidation (13), and in the number of mitochondria found in skeletal muscle, compared with age-matched insulin-sensitive subjects (12).

Mitochondrial dysfunction and increased ROS production are involved in the reduction of lipid oxidation, and the increase in lipid content in muscle cells, exacerbating IR (14). Decrease in fatty acid oxidation produces increased intracellular levels of fatty acetyl-CoA and diacylglycerol. These molecules activate protein kinase C, p38/MAPK (mitogen-activated protein kinase) and JNK (jun N-terminal kinase) which, in turn, trigger a cascade of serines, leading to increased phosphorylation of serine residues of insulin receptor-1 (IRS-1). An increase in serine phosphorylation blocks IRS-1 tyrosine residue phosphorylation, which inhibits the capacity of the receptor to phosphorylate the downstream target PI3K. Inactivation of PI3K impairs the translocation of glucose transporter type 4 (GLUT4) to the plasma membrane, and, consequently, leads to a decrease in glucose uptake in muscle cells upon insulin stimulation (14).

Furthermore, decreased ATP synthesis that results from mitochondrial dysfunction also plays an important role in decreasing insulin secretion in patients with DM2, since it may impair the regulation of $\mathrm{K}^{+}$and $\mathrm{Ca}^{+}$ channels present in the cell membrane, and thereby inhibit exocytosis of insulin granules in beta cells (10).

\section{UNCOUPLING PROTEINS (UCPS)}

UCPs $1,2,3,4$ and 5 are members of an anion-carrier protein family located in the mitochondrial inner membrane (6). These proteins have similarities in their structures, but different tissue expression in mammals. The original UCP, UCP1, is mainly expressed in brown adipose tissue, which is responsible for thermogenesis 
in newborns (15). It was recently shown that, under certain physiological conditions such as hyperglycemia, UCPl is also expressed in skeletal muscle, white adipose tissue, retinal cells and pancreatic beta cells $(16,17)$. UCP2 is widely distributed, whereas UCP3 is mainly restricted to the skeletal muscle, and UCP4 and UCP5/ BMCPl are mainly expressed in the brain $(6,15)$.

Over the last few years, several studies have shown that UCPs decrease metabolic efficiency by dissociating substrate oxidation in the mitochondria from ATP synthesis, by means of the MRC. This is thought to be accomplished by promoting net translocation of protons from the intermembrane space, across the inner mitochondrial membrane to the mitochondrial matrix, thereby dissipating the potential energy available for the conversion of ADP to ATP and, consequently, decreasing ATP production (6). This uncoupling effect then leads to homologue- and tissue-specific functions, such as thermogenesis (UCPl), regulation of FFAs metabolism and transport (UCP2 and UCP3), reduction in ROS formation (UCPl-3 and UCP5/BMCPl), and regulation of ATP-dependent processes (UCP2) $(15,18)$.

\section{UNCOUPLING PROTEIN 2 (UCP2)}

In 1997, Fleury and cols. (19) cloned and sequenced a gene homologous to UCP1 gene, later called UCP2. $U C P 2$ gene covers a $6.3 \mathrm{~kb}$ region on chromosome 11 (region $1 \mathrm{lq} 13$ ), and has eight exons and seven introns (Figure 2). In humans, region $11 q 13$ is linked to basal metabolic rate and body fat percentage (20). The transcriptional gene unit is constituted by two non-coding exons followed by six exons that encode the 308 amino acids of the protein (19). Human UCP2 share 57\% amino acid-sequence identity with human UCPl, and it is $71 \%$ identical to human UCP3 (8). In addition, the amino acid sequence of human UCP2 is $95 \%$ identical to mouse UCP2 (19).

UCP2 is expressed in a wide range of tissues and cell types, including brown and white adipose tissues, skeletal muscle, heart, kidneys, liver, lungs, spleen, thymus, bone marrow, macrophages, brain, gastrointestinal tract, pancreatic islets and retinal cells $(6,8,15,16,19)$. Although UCP2 is well expressed in many tissues at mRNA level, it would seem that UCP2 protein level is not simply proportional to mRNA concentration. For example, whereas UCP2 mRNA is found in heart, skeletal muscle, and brown adipose tissue, no UCP2 protein could be detected in these tissues (21). Thus,

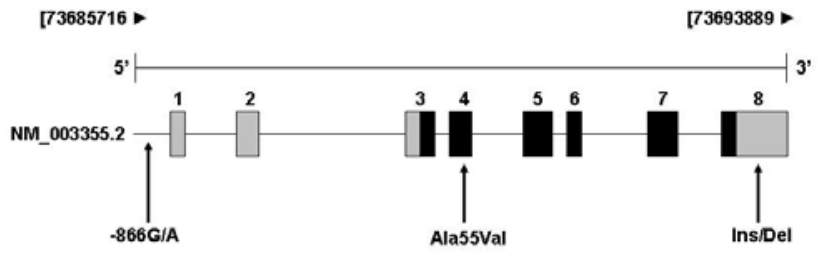

Figure 2. Map of UCP2 gene locus on chromosome 11 (region 11q13). The eight exons (boxes) are numbered from left to right according to the transcriptional region. The black boxes represent the coding regions, and the light gray boxes represent the non-coding region, including 3'UTR region of exon 8. The vertical arrows show the main common polymorphisms associated with DM2 or its microvascular chronic complications. Figure adapted from http://www.nbci.nlm.nih.gov/gene/7351.

changes in the amount of UCP2 mRNA do not always reflect the expression of the protein itself, which may be explained by different translational regulation of UCP2 gene among tissues, providing a mechanism by which its expression can be rapidly and strongly induced under stress conditions (2l). PPAR (peroxisome proliferator-activated receptor)- $\alpha$, PPAR- $\gamma$, PGC- $1 \alpha$ and SREBP-lc (sterol regulatory element binding protein-lc) transcription factors increase UCP2 gene expression, while SIRTl (sirtuin 1) and FOXAl (forkhead box $\mathrm{Al}$ ) factors inhibit its expression (22). UCP2 is also translationally regulated by an inhibitory upstream open reading frame (ORF), which, when mutated, results in maximal UCP2 mRNA translation (23). Glutamine, an amino acid that has been implicated in the insulin secretion pathway, overcomes ORF inhibition and increases UCP2 efficiency (23).

It was proposed that both UCP2 and UCP3 only mildly uncouple respiration, slightly dissipating membrane potential energy, and thus slightly decreasing ATP production $(8,18)$ (Figure 1A). Nonetheless, unlike UCP1, UCP2 and UCP3 only uncouple MRC after suitable induction by cold, ROS (particularly superoxide), ubiquinone, high levels of glucose and/or non-esterified fatty acids, high impact exercise, sepsis, and hyperthyroidism. Their activities are inhibited by purine, such as ATP and GDP, and by interleukin- $1 \beta$ $(24,25)$. As already mentioned, MRC uncoupling generated by UCP2 leads to protection from excess ROS production, while it also seems to be associated with inhibition of insulin secretion by beta cells and regulation of FFAs metabolism and transport $(18,22,26)$.

"Mild uncoupling" of MRC due to UCP2 activity allows a more rapid flux of electrons through the mitochondrial inner membrane, reducing membrane po- 
tential and decreasing ROS production (6). Since even "mild uncoupling" has a large effect on reducing ROS production, the hypothesis that UCP2 protects against oxidative stress is strongly supported and is now generally accepted (6). Accordingly, UCP2 knockout mice have elevated ROS production in macrophages (27) and pancreatic beta cells (28). Moreover, rat clonal beta cell line (INS-1E) genetically modified to overexpress UCP2 gene presented increased survival after treatment with the free radical $\mathrm{H}_{2} \mathrm{O}_{2}(29)$. Likewise, beta cells exposed to oxidative stress attempted to overcome the toxicity caused by $\mathrm{H}_{2} \mathrm{O}_{2}$ by the induction of UCP2 mRNA (24). More recently, it was demonstrated that endothelial cells from bovine retinal cells incubated with high glucose levels increased UCP2 expression, which protected them from ROS damage derived from glucotoxicity, suggesting a protective role of this protein in the pathogenesis of DR or other diabetic chronic complications (16).

An important coupling signal between glucose sensing and insulin secretion by pancreatic beta cells is the rise in $\mathrm{ATP} / \mathrm{ADP}$ ratio. Increases in $\mathrm{ATP} / \mathrm{ADP}$ ratio close the ATP-sensitive $\mathrm{K}^{+}$channel in the mitochondrial inner membrane. This causes membrane depolarization, opening of voltage-gated calcium channels, and influx of $\mathrm{Ca}^{2+}$ into the cytosol of beta cells, which subsequently triggers the exocytosis of granules containing insulin. UCP2, by virtue of its proton leak activity, decreases the generation of ATP from glucose metabolism in beta cells, which consequently impairs glucose-stimulated insulin secretion $(6,7,18,20)$. Accordingly, several studies have confirmed that UCP2 acts as a negative regulator of insulin secretion. For example, UCP2 overexpression in rat islets totally suppresses glucose-stimulated insulin secretion (30). Additionally, pancreatic islets from UCP2 knockout mice (UCP2\%) have increased insulin secretion in response to glucose. These mice have higher blood insulin and lower blood glucose than wild-type mice (26). Interestingly, double mutant $\mathrm{Lep}^{\mathrm{ob} / \mathrm{ob}} / \mathrm{UCP} 2 \%$ mice (i.e., obese and with UCP2 gene deleted) have improved beta cell function independent of obesity (26).

FFAs are endogenous physiological regulators associated with increased UCP2 and UCP3 expression in a tissue-specific manner $(18,25)$. In preadipocyte cell lines, unsaturated fatty acids markedly induce UCP2 mRNA expression (31). Other cell lines derived from heart, liver and pancreatic islets also respond to the addition of different FFAs to the culture medium with an increa- se in UCP2 mRNA levels (25). FFAs seem to regulate the UCP2 and UCP3 expression probably via PPAR- $\alpha$, PPAR $\gamma$ and SREBP-lc transcription factors (25).

Studies in proteoliposomes, isolated mitochondria and intact cells suggest that both UCP2 and UCP3 have a role in transporting FFAs or fatty acid hydroperoxides $(24,32)$. These proteins seem to export fatty acid anions outside of the mitochondrial matrix when a large excess of fatty acids is inside the mitochondria, protecting cells from the oxidative damage caused by excessive fatty acid peroxidation (lipotoxicity), mainly of polyunsaturated fatty acids of the phospholipidic membrane. These fatty acids can bind to the superoxide produced by mitochondria, which converts them to 4-hydroxy-2-nonenal (HNE), an UCP2 activator. After activation by HNE, UCP2 is able to transport protons across the mitochondrial inner membrane, thus increasing the uncoupling of MRC and, consequently, decreasing ROS formation (33).

Beta cell dysfunction can be produced by prolonged exposure of these cells to elevated glucose (glucotoxicity) and lipid (lipotoxicity) levels, conditions often associated with DM2. The exact mechanisms by which glucolipotoxicity triggers beta cell dysfunction are not well-known. However, evidence indicates that ROS production plays an important role in these mechanisms (6). As already mentioned, it is known that beta cells exposed for a prolonged time to glucolipotoxicity increase UCP2 expression in a way to protect them against damage caused by oxidative stress (22). Besides, it is clear that beta cells display low expression and activity of many of the enzymes involved in antioxidant defense. Thus, an antioxidant effect of UCP2 is of special importance in this cell type (29). However, increased UCP2 production leads to decreased insulin secretion, predisposing subjects to DM2 $(6,22,32,33)$. Therefore, UCP2 is a candidate gene for the development of DM2, since altered expression of this gene can explain some key defects involved in this disease or its chronic complications (Figure 1B).

\section{Polymorphisms in uncoupling protein 2 gene associated with type 2 diabetes mellitus}

In a number of genetic studies, the relationship between UCP2 locus and susceptibility for DM2 or obesity have been investigated, with specific attention being paid to $-866 \mathrm{G} / \mathrm{A}$ (rs659366) polymorphism in the promoter region (34); Ala55Val (C/T; rs660339) polymorphism in exon 4 (35); and Ins/Del polymor- 
phism, which is an insertion/deletion of $45 \mathrm{bp}$ in the $3^{\prime}$ UTR region (3' untranslated region) of exon 8 (36). Results of these studies have been variable: while some studies showed an association of one or more of these polymorphisms with obesity, reduced levels of insulin secretion by beta cells, IR and/or DM2 (34,37-45), other studies were unable to find any association be- tween these polymorphisms and these characteristics $(35,36,46-48)$ (Table 1$)$.

The A allele of the $-866 \mathrm{G} / \mathrm{A}$ polymorphism has been reported to increase UCP2 transcriptional activity in transfected INS-1E cells derived from rat beta cells (36). However, data in human tissues have been conflicting, reporting either increased $(36,50,51)$ or

Table 1. Studies of the association between -866G/A, Ala55Val and Ins/Del polymorphisms in UCP2 gene and type 2 diabetes mellitus

\begin{tabular}{|c|c|c|c|c|}
\hline Polymorphism & Population & Characteristics & Results & Refs. \\
\hline$-866 \mathrm{G} / \mathrm{A}$ & Danish (749 obese and 816 non-obese) & BMI, body fat content and insulin levels & No association & $(46)$ \\
\hline$-866 \mathrm{G} / \mathrm{A}$ & $\begin{array}{c}\text { Italian (483 DM2 patients and } 565 \\
\text { controls). Non-diabetic offspring of DM2 } \\
\text { patients }\end{array}$ & $\begin{array}{c}\text { DM2 } \\
\text { Insulin sensitivity in non-diabetic offspring. }\end{array}$ & $\begin{array}{l}\text { A/A genotype was associated with increased } \\
\text { risk of } D M 2 \text { in women }(O R=1.84, P= \\
0.037) \text {, but not in men. Association of } A / A \\
\text { genotype with decreased insulin sensitivity in } \\
\text { non-diabetic offspring }(P=0.01)\end{array}$ & (38) \\
\hline$-866 \mathrm{G} / \mathrm{A}$ & 301 healthy Italian white subjects & Insulin sensitivity & $\begin{array}{l}\text { Insulin secretion was higher in subjects } \\
\text { carrying } A / A \text { genotype than in those carrying } \\
G / G \text { or } A / G \text { genotype }(P<0.05)\end{array}$ & $(40)$ \\
\hline$-866 \mathrm{G} / \mathrm{A}$ & $\begin{array}{l}\text { Japanese (416 DM2 patients and } 172 \\
\text { controls) }\end{array}$ & DM2 and insulin secretion levels & $\begin{array}{l}\text { No association with DM2. Association } \\
\text { between } A \text { allele and earlier DM2 onset }(P= \\
\text { 0.042), increased frequency of insulin } \\
\text { treatment }(P=0.0027) \text {, and lower levels of } \\
\text { insulin secretion ( } P=0.016)\end{array}$ & $(34)$ \\
\hline$-866 \mathrm{G} / \mathrm{A}$ & Italian (746 DM2 patients and 118 controls) & DM2 & $\begin{array}{l}\text { A/A genotype was associated with protection } \\
\text { against } D M 2(0 R=0.51, P=0.003) \text {. }\end{array}$ & $(39)$ \\
\hline$-866 \mathrm{G} / \mathrm{A}$ & 2936 healthy middle-aged English men & $\begin{array}{l}\text { DM2 incidence in a 15-year follow-up } \\
\text { study }\end{array}$ & $\begin{array}{l}\text { A/A genotype was associated with increased } \\
\text { risk of developing } D M 2(H R=1.94 \\
\qquad P=0.009)\end{array}$ & $(41)$ \\
\hline$-866 \mathrm{G} / \mathrm{A}$ & $\begin{array}{l}\text { Austrian (391 non-diabetic controls, } 201 \\
\text { DM2 obese patients and } 39 \text { obese subjects) }\end{array}$ & $\begin{array}{c}\text { DM2 } \\
\text { Insulin sensitivity }\end{array}$ & $\begin{array}{l}\text { Genotype A/A associated with increased risk } \\
\text { of } \mathrm{DM} 2(\mathrm{OR}=2.12, \mathrm{P}=0.035)\end{array}$ & $(43)$ \\
\hline Ala55Val & $\begin{array}{l}\text { Chinese (173 DM2 patients, } 119 \text { obese } \\
\text { subjects and } 117 \text { non-diabetic controls) }\end{array}$ & DM2 and obesity & $\begin{array}{l}\text { Val/Val genotype was associated with } \\
\text { increased risk of } D M 2(O R=4.62, P= \\
0.0001) \text { and obesity }(O R=3.71, P=0.001)\end{array}$ & $(42)$ \\
\hline Ala55Val & $\begin{array}{l}3684 \text { healthy American participants of the } \\
\text { CARDIA Study }\end{array}$ & $\begin{array}{l}\text { DM2 incidence in a 15-year follow-up } \\
\text { study }\end{array}$ & $\begin{array}{l}\mathrm{Val} / \mathrm{Nal} \text { genotype was associated with higher } \\
\text { incidence of } \mathrm{DM} 2(\mathrm{OR}=1.75, \mathrm{P}=0.020)\end{array}$ & $(37)$ \\
\hline Ala55Val & $\begin{array}{l}\text { Japanese (210 DM2 patients, } 42 \text { obese } \\
\text { subjects and } 218 \text { non-diabetic controls) }\end{array}$ & DM2 and obesity & No association & (35) \\
\hline Ala55Val & 284 Swedish men & Metabolic syndrome characteristics & No association & $(47)$ \\
\hline Ins/Del & Indians (76 DM2 patients and 335 controls) & DM2 & No association & $(36)$ \\
\hline $\begin{array}{l}-866 \mathrm{G} / \mathrm{A} \text { and } \\
\text { Ala55Val }\end{array}$ & $\begin{array}{l}\text { Postmenopausal American women (1584 } \\
\text { DM2 incident cases and } 2198 \text { controls) }\end{array}$ & DM2 & No association & $(48)$ \\
\hline $\begin{array}{l}-866 \mathrm{G} / \mathrm{A} \text { and } \\
\text { Ala55Val }\end{array}$ & 22,715 healthy white American women & $\begin{array}{l}\text { Risk of incident DM2 in a 13- year } \\
\text { follow-up study }\end{array}$ & No association & $(49)$ \\
\hline $\begin{array}{l}-866 \mathrm{G} / \mathrm{A} \text { and } \mathrm{Ins} / \\
\text { Del }\end{array}$ & $\begin{array}{l}\text { Spanish children (193 obese subjects and } \\
\qquad 173 \text { controls) }\end{array}$ & Obesity and IR & $\begin{array}{l}\text { Association of }-866 \mathrm{G} \text { Del }-55 \mathrm{~T} \text { / -866G Del } \\
-55 \mathrm{~T}^{\star} \text { haplotype with increased risk of } \\
\text { obesity }(\mathrm{OR}=1.95,95 \% \mathrm{Cl} 1.43-2.65) \text { and } \\
\text { IR }(\mathrm{OR}=9.54,95 \% \mathrm{Cl} 2.28-39.9)\end{array}$ & $(45)$ \\
\hline $\begin{array}{l}-866 \mathrm{G} / \mathrm{A}, \text { Ala55Val } \\
\text { and Ins/Del }\end{array}$ & $\begin{array}{l}\text { White subjects from Northern Europe } \\
\text { (131 DM2 patients and } 118 \text { controls) }\end{array}$ & DM2 & $\begin{array}{c}\text { Association of } G \text { Val Ins / } A \text { Val Del } \\
\text { haplotype with higher } B M I(P=0.028) ; I R \\
(P=0.031) ; \text { and triglyceride }(P=0.026) \text { and } \\
\text { plasma insulin levels }(P=0.029)\end{array}$ & $(44)$ \\
\hline
\end{tabular}

${ }^{*}-55 \mathrm{C} / \mathrm{T}$ polymorphism (rs1800849) in UCP3 gene. $\mathrm{BMI}=$ body mass index. DM2 = type 2 diabetes mellitus. $\mathrm{HR}=$ hazard ratio. $\mathrm{IR}=$ insulin resistance. $\mathrm{OR}=0 \mathrm{dds}$ ratio. $95 \% \mathrm{Cl}=95 \%$ confidence interval. 
decreased $(44,52)$ UCP2 mRNA levels associated with $-866 \mathrm{~A}$ allele. Computational analyzes demonstrated that this polymorphism is involved in putative binding sites for specific transcription factors, such as PAX6 (paired box gene 6 ) and HIF-l $\alpha$ (hypoxia-inducible factor$1 \alpha)(50)$. Esterbauer and cols. (50) hypothesized that preferential binding of some transcription factors to $G$ or A allele in the promoter sequence may confer tissue-specific advantages to either allele.

Non-diabetic subjects carrying the $-866 \mathrm{~A}$ allele have been shown to have decreased insulin secretion response to intravenous and oral glucose and, therefore, have increased risk of developing DM2 $(38,40,41,43)$. Similarly, DM2 patients carrying A allele have been shown to have significantly lower insulin secretion during intravenous glucose tolerance test, and to require insulin therapy more frequently and earlier after diagnosis of the disease, than patients carrying the $\mathrm{G} / \mathrm{G}$ genotype (34). In addition, some studies also suggest that A allele carriers also seem to have a higher waist-to-hip ratio, increased risk of metabolic syndrome, and higher levels of plasma markers of oxidative stress (51).

The Ins/Del polymorphism is located in the 3' UTR region of the gene, only $158 \mathrm{pb}$ from the transcription stop codon. It also appears to be functional because mRNA transcribed from the sequence containing the insertion allele displayed a shorter half-life in a fetal myoblast cell line than mRNA transcribed from the sequence containing the deletion allele (53). In the other hand, Ala55Val $(\mathrm{C} / \mathrm{T})$ polymorphism causes a conservative amino acid change (alanine/valine) at position 55 of exon 4. Until now, there has been no evidence that this alteration generates a functional change in the protein. Thus, considering that the Ala55Val $(\mathrm{C} / \mathrm{T})$ polymorphism is tightly linked to the $-866 \mathrm{G} / \mathrm{A}$ polymorphism $\left(\left|\mathrm{D}^{\prime}\right|=0.991\right)$, and partially linked to the Ins/Del polymorphism $\left(\left|\mathrm{D}^{\prime}\right|=0.879\right)$, this polymorphism may not be a real disease-causing variant, but could simply be reflecting the effects of $-866 \mathrm{G} / \mathrm{A}$ and Ins/Del polymorphism (54).

Studies on the association of the effects of Ala55Val and Ins/Del polymorphisms on DM2 or associated characteristics have shown controversial results. Subjects carrying the Val/Val genotype of Ala55Val polymorphism seem to have increased risk of developing DM2 and obesity, and higher BMI than subjects with Ala/Val or Ala/Ala genotypes $(37,42,51,55)$. However, other studies indicated that this polymorphism is not individually associated with BMI, obesity, metabolic syn- drome, DM2, and insulin secretion $(35,44,47,48,51)$. Likewise, some studies did not find any individual association between Ins/Del polymorphism and obesity, DM2 and/or insulin secretion (44-46,51), while other studies reported an association between the insertion allele and obesity $(36,51)$.

Haplotype combinations constituted by UCP2 gene polymorphisms have also been found to be associated with BMI, obesity, insulin secretion and IR $(44,45,48)$. Wang and cols. (44) reported that the G Val Ins / A Val Del haplotype (-866G/A, Ala55Val, and Ins/Del polymorphisms $)$ is associated with higher BMI $(\mathrm{P}=0.028)$, IR $(\mathrm{P}=0.031)$ and higher plasma insulin levels $(\mathrm{P}=$ $0.029)$ in northern European white subjects with and without DM2. Ochoa and cols. (45) investigated, in a group of Spanish obese and non-obese children, the association between $-866 \mathrm{G} / \mathrm{A}$ and Ins/Del polymorphisms in the UCP2 gene and $-55 \mathrm{C} / \mathrm{T}(\mathrm{rs} 1800849)$ in UCP3 gene with obesity and IR. Although they observed no association between individual polymorphisms and these characteristics, the authors observed that the -866G Del -55T / -866G Del -55T haplotype was associated with increased risk of obesity $(\mathrm{OR}=1.9,95 \%$ CI 1.4 - 2.6) and IR (OR = 9.5, 95\% CI 2.3 - 39.9).

In brief, studies on these associations cited here indicated that the functional $-866 \mathrm{G} / \mathrm{A}$ polymorphism actually contributes to the biological variation of insulin secretion and, consequently, to the susceptibility to DM2. On the other hand, results reported by other studies on the effects of Ala55Val and Ins/Del polymorphisms on DM2 or associated characteristics are still inconclusive.

\section{Association between UCP2 gene polymorphisms and chronic complications of diabetes}

One of the main mechanisms linking hyperglycemia to diabetic microvascular and macrovascular complications is mitochondrial overproduction of $\operatorname{ROS}(3,4)$. However, despite the recognized role of UCP2 in the protection against oxidative stress, only a few studies evaluated the association between UCP2 gene polymorphisms and the occurrence of chronic complications of diabetes.

Rudofsky and cols. (56) observed that type $1 \mathrm{DM}$ patients carrying the $-866 \mathrm{~A}$ allele had significantly reduced prevalence of DPN when compared with patients homozygous for $-866 \mathrm{G}$ allele $(\mathrm{OR}=0.44,95 \%$ CI $0.2-0.8, \mathrm{P}=0.007)$. Interestingly, these authors also reported that the effect on DPN protection was 
even more intense $(\mathrm{OR}=0.28,95 \%$ CI $0.1-0.7, \mathrm{P}=$ 0.002 ) when A allele of the $-866 \mathrm{G} / \mathrm{A}$ polymorphism occurs in an haplotype containing $\mathrm{T}$ allele of $-55 \mathrm{C} / \mathrm{T}$ polymorphism in $U C P 3$ gene. The same study reported no association between the $-866 \mathrm{G} / \mathrm{A}$ polymorphism and $\mathrm{DN}$ or DR.

In addition, Rudofsky and cols. (57) did not observe any association between -866G/A polymorphism and DPN, DN or DR in DM2 patients from Germany. Lindholm and cols. (53) reported that Ins/ Del polymorphism was not associated with micro- or macroalbuminuria in DM2 patients from Scandinavia. More recently, Crispim and cols. (54) showed that A Val Ins/A Val Ins haplotype (-866G/A, Ala55Val and Ins/Del polymorphisms) was associated with increased risk of proliferative $\mathrm{DR}$, the most severe form of $\mathrm{DR}$, in both DM2 patients $(\mathrm{OR}=5.3,95 \%$ CI $2.2-12.4, \mathrm{P}<$ $0.00001)$ and type $1 \mathrm{DM}$ patients $(\mathrm{OR}=6.0,95 \% \mathrm{CI}$ 1.7 - 20.8, P = 0.005) from Rio Grande do Sul (Brazil).

In addition to the inhibition of mitochondrial production of ROS, UCP2 may also regulate inflammation and apoptosis. These functions have important implications for cardiovascular and cerebrovascular chronic complications of diabetes (58). Accordingly, Palmer and cols. (59) examined the impact of $-866 \mathrm{G} / \mathrm{A}$ polymorphism on 5 -year survival rate in a cohort of post-myocardial infarction patients, and observed no association between this polymorphism and survival in the overall cohort. However, among DM2 patients, A/A and $\mathrm{G} / \mathrm{A}$ genotype groups had significantly worse survival than $\mathrm{G} / \mathrm{G}$ diabetic patients $(\mathrm{P}<0.05)$. Moreover, Cheurfa and cols. (60) reported an inverse association between A allele of $-866 \mathrm{G} / \mathrm{A}$ polymorphism and incident cases of coronary artery disease in DM2 patients (hazard ratio $=0.88$, CI 95\% 0.8-0.9; $\mathrm{P}=0.006$ ). Stratification by sex confirmed an allele association with coronary artery disease in men, whereas no association was observed in women $(60)$.

In conclusion, DM2 and its chronic complications are multifactorial diseases associated with both genetic and environmental risk factors. Knowledge on factors associated with DM2 will allow us to better understand the disease and its chronic complications, and may provide us with more effective approaches to treatment and prevention. UCP2 plays important roles in the decrease in ROS formation by mitochondria, in negative regulation of insulin secretion by beta cells, and in the regulation of FFA metabolism. These mechanisms are associated with the pathogenesis of DM2 or its mi- crovascular complications and, in fact, several studies strongly suggest that $-866 \mathrm{G} / \mathrm{A}$ polymorphisms in the UCP2 gene may contribute to the biological variation in insulin secretion and DM2 susceptibility. Therefore, further studies characterizing the molecular basis and regulatory mechanisms of UCP2 will enable better understanding of the physiological role of this protein on the pathogenesis of obesity and DM2. Development of drugs that modulate the activity of UCP2 could, in the future, become new strategies for the treatment of DM2 or its chronic complications.

Acknowledgments: This study was partially supported by grants from the Conselho Nacional de Desenvolvimento Científico e Tecnólogico $(\mathrm{CNPq})$, and Fundo de Incentivo à Pesquisa e Eventos (FIFE) at Hospital de Clínicas de Porto Alegre. The authors would like to thank Haroldo Paraguassú de Souza for drawing figure 1.

Disclosure: no potential conflict of interest relevant to this article was reported.

\section{REFERENCES}

1. Malerbi D, Franco L. Multicenter study of the prevalence of diabetes mellitus and impaired glucose tolerance in the urban Brazilian population aged 30-69 yr. The Brazilian Cooperative Group on the Study of Diabetes Prevalence. Diabetes Care. 1992;15(11):1509-16.

2. American Diabetes Association. Diagnosis and classification of diabetes mellitus. Diabetes Care. 2010;33 Suppl 1:S62-9.

3. Fong D, Aiello L, GardnerT, King G, Blankenship G, Cavallerano J, et al. Retinopathy in diabetes. Diabetes Care. 2004;27 Suppl 1:S84-7.

4. Carpena M, Rados D, Sortica D, Souza B, Reis A, Canani L, et al. Genetics of diabetic nephropathy. Arq Bras Endocrinol Metabol. 2010;54(3):253-61.

5. Bloomgarden Z. Diabetic neuropathy. Diabetes Care. 2008;31(3):616-21.

6. Fisler J, Warden $\mathrm{CH}$. Uncoupling proteins, dietary fat and the metabolic syndrome. Nutr Metab (Lond). 2006;3:38.

7. Echtay K. Mitochondrial uncoupling proteins--what is their physiological role? Free Radic Biol Med. 2007;43(10):1351-71.

8. Dalgaard L, Pedersen O. Uncoupling proteins: functional characteristics and role in the pathogenesis of obesity andType II diabetes. Diabetologia. 2001;44(8):946-65.

9. Papa S, Skulachev V. Reactive oxygen species, mitochondria, apoptosis and aging. Mol Cell Biochem. 1997;174(1-2):305-19.

10. Wang C, Wang C, Wei Y. Mitochondrial dysfunction in insulin insensitivity: implication of mitochondrial role in type 2 diabetes. Ann NY Acad Sci. 2010;1201:157-65.

11. Patti M, Butte A, Crunkhorn S, Cusi K, Berria R, Kashyap S, et al. Coordinated reduction of genes of oxidative metabolism in humans with insulin resistance and diabetes: Potential role of PGC1 and NRF1. Proc Natl Acad Sci U S A. 2003;100(14):8466-71.

12. Kelley D, He J, Menshikova E, Ritov V. Dysfunction of mitochondria in human skeletal muscle in type 2 diabetes. Diabetes. 2002;51(10):2944-50.

13. Petersen K, Dufour S, Shulman G. Decreased insulin-stimulated ATP synthesis and phosphate transport in muscle of insulin-resistant offspring of type 2 diabetic parents. PLoS Med. 2005;2(9):e233. 
14. Lowell B, Shulman G. Mitochondrial dysfunction and type 2 diabetes. Science. 2005;307(5708):384-7.

15. Erlanson-Albertsson C. Uncoupling proteins--a new family of proteins with unknown function. Nutr Neurosci. 2002;5(1):1-11.

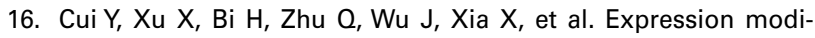
fication of uncoupling proteins and MnSOD in retinal endothelial cells and pericytes induced by high glucose: the role of reactive oxygen species in diabetic retinopathy. Exp Eye Res. 2006;83(4):807-16.

17. Sale M, Hsu F, Palmer N, Gordon C, Keene K, Borgerink H, et al. The uncoupling protein 1 gene, UCP1, is expressed in mammalian islet cells and associated with acute insulin response to glucose in African American families from the IRAS Family Study. BMC Endocr Disord. 2007;7:1.

18. Chan C, Saleh M, Koshkin V, Wheeler M. Uncoupling protein 2 and islet function. Diabetes. 2004;53 Suppl 1:S136-42.

19. Fleury C, Neverova M, Collins S, Raimbault S, Champigny O, Levi-Meyrueis $C$, et al. Uncoupling protein-2: a novel gene linked to obesity and hyperinsulinemia. Nat Genet. 1997;15(3):269-72.

20. Krauss $S$, Zhang $C$, Lowell B. The mitochondrial uncoupling-protein homologues. Nat Rev Mol Cell Biol. 2005;6(3):248-61.

21. Pecqueur $C$, Alves-Guerra M, Gelly $C$, Levi-Meyrueis $C$, Couplan $\mathrm{E}$, Collins $\mathrm{S}$, et al. Uncoupling protein 2, in vivo distribution, induction upon oxidative stress, and evidence for translational regulation. J Biol Chem. 2001;276(12):8705-12.

22. Affourtit $\mathrm{C}, \mathrm{Brand} M$. On the role of uncoupling protein-2 in pancreatic beta cells. Biochim Biophys Acta. 2008;1777(7-8):973-9.

23. Azzu V, Jastroch M, Divakaruni AS, Brand MD. The regulation and turnover of mitochondrial uncoupling proteins. Biochim Biophys Acta. 2010;1797(6-7):785-91.

24. Esteves T, Brand M. The reactions catalysed by the mitochondrial uncoupling proteins UCP2 and UCP3. Biochim Biophys Acta. 2005;1709(1):35-44.

25. Thompson M, Kim D. Links between fatty acids and expression of UCP2 and UCP3 mRNAs. FEBS Lett. 2004;568(1-3):4-9.

26. Zhang $C$, Baffy G, Perret $P$, Krauss $S$, Peroni $O$, Grujic $D$, et al. Uncoupling protein-2 negatively regulates insulin secretion and is a major link between obesity, beta cell dysfunction, and type 2 diabetes. Cell. 2001;105(6):745-55.

27. Arsenijevic $D$, Onuma $H$, Pecqueur $C$, Raimbault $S$, Manning $B$, Miroux $B$, et al. Disruption of the uncoupling protein-2 gene in mice reveals a role in immunity and reactive oxygen species production. Nat Genet. 2000;26(4):435-9.

28. Krauss S, Zhang C, Scorrano L, Dalgaard L, St-Pierre J, Grey $\mathrm{S}$, et al. Superoxide-mediated activation of uncoupling protein 2 causes pancreatic beta cell dysfunction. J Clin Invest. 2003;112(12):1831-42.

29. Li L, Skorpen F, Egeberg K, Jørgensen I, Grill V. Uncoupling protein-2 participates in cellular defense against oxidative stress in clonal beta-cells. Biochem Biophys Res Commun. 2001;282(1):273-7.

30. Chan $C$, MacDonald $P$, Saleh $M$, Johns $D$, Marbàn E, Wheeler M. Overexpression of uncoupling protein 2 inhibits glucose-stimulated insulin secretion from rat islets. Diabetes. 1999;48(7):1482-6.

31. Reilly J, Thompson M. Dietary fatty acids Up-regulate the expression of UCP2 in 3T3-L1 preadipocytes. Biochem Biophys Res Commun. 2000;277(3):541-5.

32. Azzu V, Brand M. The on-off switches of the mitochondrial uncoupling proteins. Trends Biochem Sci. 2010;35(5):298-307.

33. Brand M, Affourtit C, Esteves T, Green K, Lambert A, Miwa S, et al. Mitochondrial superoxide: production, biological effects, and activation of uncoupling proteins. Free Radic Biol Med. 2004;37(6):755-67.

34. Sasahara M, Nishi M, Kawashima H, Ueda K, Sakagashira S, Furuta $\mathrm{H}$, et al. Uncoupling protein 2 promoter polymorphism -866G/A affects its expression in beta-cells and modulates clinical profiles of Japanese type 2 diabetic patients. Diabetes. 2004;53(2):482-5.

35. KubotaT, Mori H, TamoriY, Okazawa H, FukudaT, Miki M, et al. Molecular screening of uncoupling protein 2 gene in patients with noninsulin-dependent diabetes mellitus or obesity. J Clin Endocrinol Metab. 1998;83(8):2800-4.

36. Cassell P, Neverova M, Janmohamed S, Uwakwe N, Qureshi A, McCarthy $M$, et al. An uncoupling protein 2 gene variant is associated with a raised body mass index but not Type II diabetes. Diabetologia. 1999;42(6):688-92.

37. Yu X, Jacobs DJ, Schreiner $P$, Gross $M$, Steffes $M$, Fornage M. The uncoupling protein 2 Ala55Val polymorphism is associated with diabetes mellitus: the CARDIA study. Clin Chem. 2005;51(8):1451-6.

38. D'Adamo M, Perego L, Cardellini M, Marini M, Frontoni S, Andreozzi $F$, et al. The -866A/A genotype in the promoter of the human uncoupling protein 2 gene is associated with insulin resistance and increased risk of type 2 diabetes. Diabetes. 2004;53(7):1905-10.

39. Bulotta A, Ludovico O, Coco A, Di Paola R, Quattrone A, Carella $\mathrm{M}$, et al. The common -866G/A polymorphism in the promoter region of the UCP-2 gene is associated with reduced risk of type 2 diabetes in Caucasians from Italy. J Clin Endocrinol Metab. 2005;90(2):1176-80.

40. Sesti G, Cardellini M, Marini M, Frontoni S, D'Adamo M, Del Guerra $S$, et al. A common polymorphism in the promoter of UCP2 contributes to the variation in insulin secretion in glucose-tolerant subjects. Diabetes. 2003;52(5):1280-3.

41. Gable D, Stephens J, Cooper J, Miller G, Humphries S. Variation in the UCP2-UCP3 gene cluster predicts the development of type 2 diabetes in healthy middle-aged men. Diabetes. 2006 May;55(5):1504-11.

42. Xiu L, Weng J, Sui Y, Wang J, Yan J, Huang Z. [Common variants in beta 3-adrenergic-receptor and uncoupling protein-2 genes are associated with type 2 diabetes and obesity]. ZhonghuaYi Xue Za Zhi. 2004;84(5):375-9.

43. Krempler $F$, Esterbauer $H$, Weitgasser $R$, Ebenbichler $C$, Patsch $\mathrm{J}$, Miller $\mathrm{K}$, et al. A functional polymorphism in the promoter of UCP2 enhances obesity risk but reduces type 2 diabetes risk in obese middle-aged humans. Diabetes. 2002;51(11):3331-5.

44. Wang H, Chu W, Lu T, Hasstedt S, Kern P, Elbein S. Uncoupling protein-2 polymorphisms in type 2 diabetes, obesity, and insulin secretion. Am J Physiol Endocrinol Metab. 2004;286(1):E1-7.

45. Ochoa MC, Santos JL, Azcona C, Moreno-Aliaga MJ, Martínez-González MA, Martínez JA, et al. Association between obesity and insulin resistance with UCP2-UCP3 gene variants in Spanish children and adolescents. Mol Genet Metab. 2007;92(4):351-8.

46. Dalgaard L, Andersen G, Larsen L, Sørensen T, Andersen T, DrivsholmT, et al. Mutational analysis of the UCP2 core promoter and relationships of variants with obesity. Obes Res. 2003;11(11):1420-7.

47. Rosmond R, Bouchard C, Björntorp P. Lack of association between the uncoupling protein-2 Ala55Val gene polymorphism and phenotypic features of the Metabolic Syndrome. Biochim Biophys Acta. 2002;1588(2):103-5.

48. HsuYH, Niu T, Song Y,Tinker L, Kuller LH, Liu S. Genetic variants in the UCP2-UCP3 gene cluster and risk of diabetes in the Women's Health Initiative Observational Study. Diabetes. 2008;57(4):1101-7.

49. Zee RY, Ridker PM, Chasman DI. Mitochondrial uncoupling protein gene cluster variation (UCP2-UCP3) and the risk of incident type 2 diabetes mellitus: the Women's Genome Health Study. Atherosclerosis. 2011;214(1):107-9.

50. Esterbauer H, Schneitler C, Oberkofler H, Ebenbichler C, Paulweber $\mathrm{B}$, Sandhofer $\mathrm{F}$, et al. A common polymorphism in the promoter of UCP2 is associated with decreased risk of obesity in middle-aged humans. Nat Genet. 2001;28(2):178-83.

51. Jia JJ, Zhang X, Ge CR, Jois M. The polymorphisms of UCP2 and UCP3 genes associated with fat metabolism, obesity and diabetes. Obes Rev. 2009;10(5):519-26. 
52. Oberkofler $\mathrm{H}$, Iglseder B, Klein K, Unger J, Haltmayer M, Krempler F, et al. Associations of the UCP2 gene locus with asymptomatic carotid atherosclerosis in middle-aged women. Arterioscler Thromb Vasc Biol. 2005;25(3):604-10.

53. Lindholm E, Klannemark M, Agardh E, Groop L, Agardh CD. Putative role of polymorphisms in UCP1-3 genes for diabetic nephropathy. J Diabetes Complications. 2004;18(2):103-7.

54. Crispim D, Fagundes N, dos Santos K, Rheinheimer J, Bouças $A$, de Souza B, et al. Polymorphisms of the UCP2 gene are associated with proliferative diabetic retinopathy in patients with diabetes mellitus. Clin Endocrinol (Oxf). 2010;72(5):612-9.

55. Walder K, Norman RA, Hanson RL, Schrauwen $P$, Neverova M, Jenkinson $\mathrm{CP}$, et al. Association between uncoupling protein polymorphisms (UCP2-UCP3) and energy metabolism/obesity in Pima indians. Hum Mol Genet. 1998;7(9):1431-5.

56. Rudofsky G, Schroedter A, Schlotterer A, Voron'ko OE, Schlimme $\mathrm{M}$, Tafel J, et al. Functional polymorphisms of UCP2 and UCP3 are associated with a reduced prevalence of diabetic neuropathy in patients with type 1 diabetes. Diabetes Care. 2006;29(1):89-94.

57. Rudofsky G, Schrödter A, Voron'ko OE, Schlotterer A, Humpert PM, Tafel J, et al. Promoter polymorphisms of UCP1, UCP2, and UCP3 are not associated with diabetic microvascular complications in type 2 diabetes. Horm Metab Res. 2007;39(4):306-9.

58. Mattiasson G, Sullivan PG. The emerging functions of UCP2 in health, disease, and therapeutics. Antioxid Redox Signal. 2006;8(12):1-38.

59. Palmer BR, Devereaux CL, Dhamrait SS, Mocatta TJ, Pilbrow AP, Frampton CM, et al. The common G-866A polymorphism of the UCP2 gene and survival in diabetic patients following myocardial infarction. Cardiovasc Diabetol. 2009;8:31.

60. Cheurfa N, Dubois-Laforgue D, Ferrarezi DA, Reis AF, Brenner GM, Bouché $\mathrm{C}$, et al. The common $-866 \mathrm{G}>\mathrm{A}$ variant in the promoter of UCP2 is associated with decreased risk of coronary artery disease in type 2 diabetic men. Diabetes. 2008;57(4):1063-8. 